\title{
Civil Society Fragmentation and Agrarian Reform: Focus on CARPER in the Philippines*
}

\author{
MARK STEVENSON CURRY**
}

Civil society fragmentation may have significant implications for rural development initiatives, such as agrarian reform program implementation. This paper assesses the issue by looking at civil society participation and cleavages in the enactment of the 2009 Comprehensive Agrarian Reform Program Extension with Reforms (CARPER) in the Philippines. CARPER was promoted by a coalition of social and political movements, including the Catholic Church and peasant and farmer groups aligned with centre-left political organizations. It was however opposed by two discordant groups: the leftist national democratic bloc of people's organizations and legislators, and conservative landlords. A Gramscian framework is adapted to describe the hegemonic relations affecting three engaged organizations from the civil society spectrum and to assess potential convergences among them.

Keywords: Civil Society Fragmentation, Participation in Development, Hegemony, Agrarian Reform, CARPER

The author would like to thank the two anonymous reviewers of the paper and the staff of ISR. He would also like to acknowledge debts of gratitude to Airah Cadiogan, Greg Robinson, Dawn Davies and Michele Olsen, Saul Miller, Jeremy Meyer and Alex Moore for their unstinting support and input.

** De La Salle University; E-mail: mark.curry@dlsu.edu.ph 


\section{INTRODUCTION}

In 2009, the Philippines was the site of an intense national campaign to enact the Comprehensive Agrarian Reform Program Extension with Reforms (CARPER) law, a continuation of the Comprehensive Agrarian Reform Program (CARP) that had expired in 2008 after twenty years of existence under the mandate of the state's Department of Agrarian Reform (DAR). CARPER was promoted by a broad coalition of social and political organizations, including the influential Catholic Church and local networks of peasant and farmer groups aligned with centre-left national political and non-government organizations. ${ }^{1}$ These groups argued that extending the CARP was essential to ensure the continuation of agrarian reform implementation by providing additional funding for the next five years (Flores-Obanil 2010, 3). On the other hand, CARPER was opposed by two discordant groups. One was the leftist National Democrat (ND) bloc of people's organizations and legislators ${ }^{2}$ that have been pushing for a socialist Genuine Agrarian Reform Program (GARP). They accused CARPER of being another "bogus" repressive legal instrument that would permit big landowners enough loopholes to further escape land redistribution (Olea 2009). The other opposition group consisted ironically of conservative landlord legislators whose interests in principle are diametrically opposed to those of the ND bloc but who nonetheless opposed CARPER on the basis of its expected failure to genuinely help the plight of small farmers (See $14^{\text {th }}$ Congress 2009a, 480-486; 2009b, 620-649). This apparent anomaly makes the Philippine case keenly interesting for scholarship about state and civil society relations, particularly civil society fragmentation vis-à-vis the state's agrarian reform program. Importantly, it raises questions about the prospects of agrarian reform implementation and rural development in the Philippines.

In many attempts to discuss civil society participation, specifically in agrarian reform, farmers or peasant workers, as represented by civil society or people's organizations, are made to stand as one entity opposite the state or agrarian reform program implementers (see Hickey and Mohan 2004). This configuration, however neat, fails to note that people's participation in general may be restricted by non-state actors or civil society organizations themselves (Bebbington and Thiele 1993). Such fragmentations or schisms within civil 
society are especially pronounced in contexts with complex histories of social movements, as in the case of the Philippines, where one group may be excluded in the interests of another (Fox 1990, 11; Heredia et al. 2006, 298; Reid 2008, 33-37). These exclusions resulting from historical impasse, internal conflicts or selective participation among civil society actors tend to manifest strongly with respect to land reform issues and campaigns (See Sadomba and Helliker 2010). Bebbington and Thiele $(1993,14)$ have argued that because agriculture still serves as the primary source of livelihood and income for most of the populations in developing countries, including the Philippines, it thus invokes higher levels of debate and disagreement among stakeholders.

The case of the CARPER campaign in the Philippines presents a notable development in state-civil society relations in the country. In particular, it offers a novel position from which to investigate Antonio Gramsci's "hegemonic processes" (Roseberry 1994) or the relations between and among the dominant and "subaltern" classes in the country based on Gramsci's thesis on hegemony and counter-hegemony. The configuration of powers in this equation explains Gramsci's relevance to Philippine agrarian relations. Hegemonic forces include the central state headed by the former president, Gloria Macapagal-Arroyo, provincial landowners who hold legislative power or influence, and conservative authorities of the Catholic Church. Subaltern groups, on the other hand, include rural farmers and agricultural laborers represented by the left-centrist 'Social Democrats' (SD) alliance and the leftist ND bloc of organizations. A Gramscian analysis offers ways of understanding the relations between and among these forces and the respective differential intensities of these relations (Roseberry 1994)-notably evidenced by the Catholic Church's provisional support for CARPER. This paper thus sets out to describe civil society fragmentations observed throughout the 2009 CARPER campaign in the Philippines and to analyze the potential implications these may have on agrarian reform implementation and rural development in general.

A Gramscian framework is adapted in this analysis for four reasons. First, other frameworks are limited in their ability to explain the CARPER campaign anomalies in a number of ways. For example, "clientelism", "patronage politics," "neopatrimonialism" and "cacique democracy" (see Sidel 1995 and Franco 
2000) have been explored in depth without eliminating a tendency to be conceptually "amorphous and sensitive" (Ncube 2010, 3). Also, Amartya Sen's (2000) approach to aspects of the politics of development by way of 'substantive' and 'instrumental' freedoms does not adequately recognize or account for the shifting intensities and unusual alignments between and within bloc forces; neither does Sen's (2000) approach offer much challenge to the neoliberal orthodoxy within which it came to prominence. In this sense, therefore, hegemony and counter-hegemony offer greater interpretive value given Gramsci's contention that civil society plays a role in obtaining consent among the subordinate classes for the legitimacy of the forces governing them (Hedman 2006, 7).

Secondly, as Benedict Kerkvliet (1991, 10-11) outlines, Gramscian interprettive analysis offers a way of observing not only the contest over the distribution of resources but the ways by which norms and rules shift, the way consensus configures and fragments, and the emergence of new values in the challenges of political life. In other words, it is a necessarily historical-based analysis. Thirdly, following Epifanio San Juan's $(2013,167)$ adaptation, Gramsci's insistence on particular cultural and national characteristics enables an understanding of the apparent contradictions of civil society participation over a single issue like CARPER in the Philippine context. Fourthly, and most intriguingly, the Gramscian approach takes the non-unified nature of subaltern classes as definitive and examines the condition of their affiliation or resistance to dominant political forces and what strategies they thereby use to influence the prevailing agenda or rework it to further their own aims, as Roseberry $(1994,358)$ argues.

In terms of this framework, and following the methodologies of Suarez (2013) and Ncube (2010), the paper employs a qualitative approach involving in-depth interviews with leaders and key persons of three local civil society organizations that engaged directly in the 2009 CARPER campaign. These organizations were purposively selected because of their respective positions regarding the CARPER initiative. ${ }^{3}$ Based on data gathered from the interviewees and the literature review, the paper assesses the possibilities among civil society organizations for convergence and the costs of divergence with respect to agrarian reform implementation and development for the rural poor. 


\section{LITERATURE REVIEW}

The literature on civil society participation in agrarian reform has been steadily expanding alongside ongoing rural democratization processes in Latin America and, to a lesser extent, Africa and Southeast Asia. As the space for peasant organizations in developing countries to participate in local and national politics increased, so did the analytic concerns of scholars interested in rural socio-political processes and "peasant politics" (Fox 1990, 3). Over the last several decades, theoretical discussions have tackled peasant-led upheavals and organized rebellions (e.g. Wolf 1969; Tilly 1975; Skocpol, 1979; Moore 1967) to so-called "everyday forms" of resistance in the countryside (e.g. Hobsbawm 1974; Scott 1986; Scott and Kerkvliet 1986; Kerkvliet 1991), and the intermediate social and political dynamics that figure in between (see Fox 1990). Not co-incidentally, this period also saw the introduction of Market-Led Agrarian Reform (MLAR) as a way to encourage growth in the agricultural sector across the developing world (Lahiff et al. 2007, 1420). MLAR is part of a broader neoliberal agrarian restructuring that champions the 'willing buyer, willing seller' model of property rights over state-led land reform initiatives (Wolford 2005; Akram-Lodhi 2007). According to Borras (2003, 370) and Akram-Lodhi (2007, 1438), MLAR represents the latest attempt to redistribute land in the context of market-oriented reforms that began under World Bank-prescribed structural adjustment programs. Akram-Lodhi, Borras and Kay (2007, xv) argue that because MLAR has ultimately deprived peasant farmers of their access to land and livelihoods, it has led to the renewed formation and strengthening of independent peasant organizations and proagrarian reform national political coalitions. Altogether these social and political developments have created wider spaces and opportunities for civil society to directly participate in debate and action on agrarian reform (Moyo and Yeros 2005, 10).

Empirical contributions to civil society participation in agrarian reform have largely focused on Latin America. This is arguably because of the region's experiences under failed neoliberal regimes and its long history of peasant mobilization and organization, the Chiapas rebellion in Mexico and Cuba's revolution being examples (see Petras 1997; Harvey 1998). Also, more 
recently in Latin America, left wing governments have become predominant and civil society has been fundamentally reorganized to reflect this change (see Keane 2012). In comparison with Africa and Asia, Latin American peasant mass movements are thus more organized, more ideologically unified, and possess more political influence from the rural village level to the federal or national level (Moyo and Yeros 2005; Aguilar 2005). One particular case that figures prominently in the studies on the region is the Rural Landless Workers' Movement (MST) in Brazil (e.g. Fernandes 1999; Navarro 2000; Robles 2001; Wolford 2003; 2005; 2010). The MST's achievements in forcing the hand of the state to redistribute land and implement agrarian reform on their terms are noteworthy, and have not been seen in other contexts (Heredia et al. 2006, 280).

Despite the abovementioned differences, civil society participation in agrarian reform in Latin America shows commonalities with the Philippines. Fox $(1990,6)$ earlier observed that the Philippine experience with land distribution and peasant participation under colonial and neocolonial administrations, as well as during transitions from dictatorship to democracy, is comparable to that of Latin American countries like Brazil, Mexico and Colombia. Moyo and Yeros (2005) also note the similarities in the organization strategies of peasant movements under neoliberal regimes in Brazil and the Philippines, among other countries. However, Philippine reality diverges from the Latin American experience in respect of at least two critical factors. Firstly, Putzel (1992), Riedinger (1995), among others, detail the reassertion of control by previously excluded and reinvented elites. Secondly, the important ideological split among major civil society organizations that occurred in the post-Marcos era has not been overcome until the present and has had long-term implications for peasant participation in agrarian reform (Reid 2000; 2008; Boudreau 2001; Weekley 2001).

\section{Civil Society Participation and Fragmentation in the Philippines}

In his discussion of rural land struggles in Asia, Filomeno Aguilar (2005, 210) reiterated the importance of context in analyzing political engagement of peasants. This is especially relevant in studies focusing on the Philippines, in 
light of the crucial splits that happened within civil society during the transition to democracy from dictatorship under Ferdinand Marcos. Indeed, although civil society in the Philippines exhibited extraordinary capacity during the 'People Power' movement of 1985 1986 to bring together disparate civil society organizations (CSO) to overthrow the Marcos dictatorship (see Hedman 2006, 10), subsequent mobilization, particularly with respect to land reform, has been less successful.

A problem for CSO and pro-peasant organizations in the Philippines is their varying capacities to stake out autonomies from the state while exercising democratic bargaining rights within it (see Franco 2000, 47). Furthermore, the Philippine context is especially contentious partly because the development ideology of the radical activist bloc, the National Democrats, is extremely suspicious of the participatory role and intentions of state and landed elites in agrarian reform, not least since they historically constitute the same entity with mutual interests (Putzel 1992, 183-186; Franco 2000, 42; Franco and Borras 2005, 26). On the other hand, centre-of-left reformist organizations, such as Pakisama, CentroSaka, and those affiliated with Akbayan Citizen's Action Party, deployed a 'critical collaborator' stance, which ultimately led to the passage of the CARPER bill (Flores-Obanil 2010).

The history of this division, or fragmentation, has been studied in detail by Reid (2000; 2008), Franco (2000), Weekley (2001), Boudreau (2001), and Franco and Borras (2005), among others. Boudreau (2001, 8-9), in particular, sets out in detail a conceptual map of the complexity and interrelations among the disparate entities of the Philippine political landscape. Two keys to this mapping are, first, that in 1986 a wide variety of organizations and movements united under the single purpose of ousting President Ferdinand Marcos (Boudreau 2001, 42) and, second, that a particular split occurred between the unified, far left National Democrats and the center-left, loosely assigned 'Social Democrats.' The decision to boycott the 1986 elections by the former is crucial (Abinales and Amoroso 2005, 236-238): it became cemented in Reaffirmism versus Rejectionism as a philosophical and strategic impasse since the early 1990s after a messy struggle in the late 1980s (Abinales and Amoroso 2005, 267; Reid 2000, 41-43; 63; Franco 2000, 126-127). Nevertheless, as de Jesus $(1982,448-449)$ posits, Manichean opposites such as masses versus 
elites or right versus left are self-limiting and paradox-bound given the Philippine history of transgressive alignments, collaborations and position switching.

The consequences of the CARPER campaign are thus a deeply contested space for the ideas and interests of different civil society groups, resulting in a new rift between two significant blocs in people's organizations in the Philippines. At least three concerns are elicited here. One, land owners' interests paradoxically become aligned with those of the far left National Democrats. Secondly, center-of-left organizations face the pyrrhic problem of winning the CARPER battle but struggling to get actual, direct attention towards landless and dispossessed communities. Thirdly, contrasting grassroots positions harden rather than seek to build new networks of mutually supportive relations across ideological differences.

\section{STUDY FRAMEWORK}

To analyze civil society participation and fragmentation in the 2009 CARPER campaign, two approaches are of importance to this study because of how aptly they relate to civil society operations and discourses. The first approach is Antonio Gramsci's depiction of civil society as a fundamental yet mutable second tier through which, without necessary force, states obtain and maintain consent for the legitimacy of their rule (Hedman 2006, 7). The second approach is Amartya Sen's (2000) discussion on how civil society is driver for efforts to achieve instrumental freedoms such as are included in the Millennium Development Goals. Pratt (2004) and Suarez (2013) give examples of the usefulness of such an eclectic or mixed theoretical interpretation of findings.

As Reid $(2008,11)$ notes, Gramsci's ideas have been necessarily assimilated and summarized for concrete use by scholars owing to the fragmentary and discursive nature of the original writings. A key concept in Gramsci's writings that has become useful for scholarship is hegemony. Hegemony describes the ruling bloc's ability to assume and maintain control by the consent of the ruled rather than by coercion, force or violence. In other words, the ruled give "conscious attachment to or agreement with central elements of the prevailing order", which includes the distribution of resources (Kerkvliet 1991, 260). In forging an ideological consensus of this kind, the role played by 
education and culture is indispensible. Hegemony thus involves both physical dominance in terms of the military and police and cultural dominance achieved by institutionally transmitting the ideas and values of the dominant group or classes (see Roseberry 1994, 359; Hedman 2006, 7; Pratt 2004, 7). The dominated thus give tacit or vocal license to the forces of control that operate on their everyday lives. And, as Reid $(2008,14)$ observes, civil society in terms of schools, churches and social clubs is both traditional and always present in the dissemination of these forces. Counter-hegemony, an idea derived from Gramsci, results when civil society is alienated by the ruling forces. Social consciousness can operate on this alienation to identify and explicate the ruling bloc's implicit contradictions. This involves a 'war of position': a strategy to bring about concrete political change through forging an alliance of social movement interests.

Importantly, Roseberry $(1994,360)$ notes that hegemony may be viewed as a concept "not to understand consent but to understand struggle." Therefore, the value of analyzing "hegemonic processes," as he terms it, lies in the surfaceing of "weakness and cleavage, of alliances unformed and class fractions unable to make their particular interests appear to be the interests of a wide collectivity" (365). This can be done by examining who the subordinate and dominant classes are based on the "field of force" or the specific configuration of powers in a given event or context. Taken together, these ideas are a useful instrument for analyzing the results of the 2009 CARPER campaign.

As mentioned earlier, Pratt (2004, 3-4) illustrates the use of an eclectic theoretical approach in order to understand more closely the micro processes, networking and anchoring in communities that is of concern to neo-Gramscian analysis and is easily elided in single-theory or single-discipline approaches. Sen's (2000) ideas on prior or substantive freedoms and instrumental freedoms, such as the right to basic health care and education, posit CSOs as privileged or specially enabled conduits between state/donor and recipient/beneficiary in a way that accords CSOs an apparent independence and constituted freedom. Sen's (2000) approach, however, offers no alternative to the neoliberal paradigm within which it originated. Gramscian propositions, by contrast, posit CSOs as fundamentally political in that they either give license to the state and the ruling elite, and legitimize the policies and measures that govern their 
existence and ability to function, or they are active in promoting social consciousness to develop an alternative distribution of resources and a reorganized historical understanding of, for example, the nature and causes of poverty. Sen's (2000) program is thus concerned with 'unpacking' the present but thereby effectively relegating historical forces. Conversely, Gramsci's approach is fundamentally historical: it allows for an explanation of decisions and policies supported by CSOs based on a continuum of struggle between hegemonic and counter hegemonic forces.

In the following sections, the ideas of Sen and Gramsci outlined above are used to analyze the responses of key CSO leaders who were directly involved in the CARPER campaign from pro- and anti-perspectives.

\section{DISCUSSION}

\section{Agrarian Reform in the Philippines: Resistance and Consolidation}

To briefly expound on the context for agrarian reform in the Philippines, American colonial control from the end of the $19^{\text {th }}$ Century, as immediate successor to Spanish domination, exacerbated extractive and exploitative conditions rather than alleviated them (Franco 2000, 37-38, 72; Borras 2008, 3-6). Furthermore, U.S. control instituted the landed oligopoly as the legislative controllers of the archipelago; and, in the promotion of a cash crop export economy, drew large numbers of the rural population into entrenched conditions of economic and social servitude. Historically, Philippine peasant resistance over unjust relations on the land has been continuous in differing degrees of intensity since at least 1745 , the date of a major uprising against the religious orders that dominated agricultural land holdings in the Spanish colonial era (McAndrew 1994, 19; Franco 2000, 64).

Responses to the struggle over land control, use and ownership have involved a range of political ploys. Prior to the Japanese occupation in 1942, this included the eviction and transplantation of tenant farmers from politically sensitive areas of Luzon to other parts of the archipelago, notably to Mindanao under Manuel Quezon's presidential policies (Escalante 2002, 1; Franco 2000, 88). To the extent that this reduced contested land rights in Luzon, it mul- 
tiplied problems in the south of the archipelago. In a Gramscian conception, these acts of state force were met and responded to through "wars of maneuver" by two major movements. First, the Sakdalistas were a radical populist party that fomented an uprising in Luzon in 1935 to protest against U.S. occupation and elite control over their lives and livelihoods (see Ileto 1979, 14-16; Abinales and Amoroso 2005, 150-152). The second, the Hukbalahap (Huks Rebellion), was directed against the Japanese occupation and its Philippine collaborators to end rural debt bondage, usury and structural impoverishment under exploitative landlords. The Huks were active from 1946 to 1954 until they were eventually decimated through combined U.S. and Philippine state force (see Kerkvliet 1979, 65-67).

President Magsaysay attempted some limited land reform initiatives in the 1950s, according to David Wurfel $(1988,15)$, to neutralize any remaining Huk rebels on their own terms. However, this achieved little, in part because both tillers and owners of the land were not capable of being mutually placated and landowners dominated the legislature so securely that change to the ownership status quo was effectively sterilized (McAndrew 1994, 45; Abinales and Amoroso 2005, 182). According to David Wurfel $(1988,169)$ only under President Ferdinand Marcos in the 1970s did significant land reform implementation occur through force of his assumed dictatorial powers. However, this was limited to rice and corn production, and was staged experimentally in places like Neuva Ecija in Luzon to quell popular opposition to his rule in an area that was traditionally prone to peasant-led uprisings (see Calderon 1978, i).

Calderon's (1978) explanation of this land reform scheme following Marcos's Presidential Decree No. 27 of 1972 reveals several important ideas for this paper in the context of peasant participation in agrarian reform. Firstly, the reform measures were deliberately technocratic or centrally planned, accommodating the institutional concerns of multiple state agencies. This excluded the preferences or perspectives of farmers themselves, whose perceived backwardness was a factor in their very exclusion (Calderon 1978, 2, 7). Secondly, the need for access to credit, roads and post-harvest facilities, marketing and chemical inputs, which were essential to make a success of reform initiatives, effectively crowded out any peasant participation (Calderon 1978 , 5). The era after Marcos is thus fundamental to an understanding of the 
seriousness of the land issue and the importance of civil society insistence for a concerted agrarian reform program, which eventually gave rise to the Comprehensive Agrarian Reform Program (CARP). This in turn provides explanations for how bitterly contested was the CARPER campaign of 2008-2009.

\section{The 1988 Comprehensive Agrarian Reform Program (CARP) and its 2009} Extension

The Comprehensive Agrarian Reform Law (CARL), emphasizing the return of the land to those who worked it, was the centerpiece to the new democratic constitution enshrined in 1987 under President Corazon Cojuangco Aquino, following the 1986 'People Power Revolution' (Abinales and Amoroso 2005, 234). Redistributive land reform was thus originally drafted during what was deemed an opportune time for left-of-centre politics (Riedinger 1995, 13). However, obstacles to its realization surfaced almost immediately via presidential hesitancy amid struggles for legitimacy from both the far left and the far right; congressional delays, dilution of the terms via loophole clauses, exemptions, and demands for landlord compensation; and outbreaks of violence between landless peasants and the state, most notably the Mendiola Bridge massacre of 19 farmers on January 22, 1987 (Riedinger 1995; Putzel 1992, 221; Borras 2001, 546). President Aquino herself was severely compromised since her elite landed family owned a 6,435-hectare sugar estate, Hacienda Luisita, located north of Manila (Abinales and Amoroso 2005, 235). Distribution of this estate to its tenants has remained a perennial flash point in owner-tenant politics and only recently been given unanimous adjudication by the Supreme Court (Business World 2011).

Since the enactment of CARP in 1988, its poor implementation was attributed to a number of factors including a lack of leadership of the Department of Agrarian Reform (DAR), shortfalls in budgetary allotments; the capacity of owners to evade requirements; and the conversion of estates into residential or industrial lots (Bello 2009, 52-58). While a statistical analysis conducted by Reyes $(2002,20-46)$ shows that agrarian reform had a positive impact on farmer beneficiaries in terms of higher real per capita income and reduced poverty incidence between 1990 and 2000, Borras and others (2009, 
14) point out that the DAR has achieved far less than it set out to do, and less even than it claimed of its targets. Gross figures suggest that $6,000,000$ hectares was distributed to $3,000,000$ beneficiary families over the 20 years of CARP's implementation (Borras et al. 2009, 14); but since much of this distribution did not represent agricultural land covered by CARP but made use of public, marginal or idle lands, or even distributions purely on paper for bureaucratic purposes, an area of 30 per cent less may constitute fair representtation (Borras 2008, 9; Bello 2009, 80; Riedinger 1995, 194). The least budgeted and most limited land distributions are reported by Bello $(2009,57)$ as having taken place under the presidency of Gloria Macapagal-Arroyo from 2001 to 2010.

By the end of CARP's allotted period of implementation, it had become what Bello $(2009,65)$ terms an "orphan program". Its achievements in having come to life at all were offset by various stalemates: ideological exhaustion, interminable political and financial costs, and population growth outstripping productive possibilities. As the Philippines became more industrialized, populated, and tourism-oriented, land prices and the pressure by developers for conversion of "rice bowl" agricultural zones, such as in Cavite and Batangas in Luzon, became clamorous (Serote 2004, 302; Bello 2009, 51-52; McAndrew 1994, xii-xiii). Add to this, annual weather calamities, particularly during harvest season, as Boudreau $(2001,44)$ and Ofreneo and Serrano $(1991,3)$ note, further adversely affect any effort to implement and sustain agrarian development.

For many observers, particularly landlord legislators, the opportunity to let CARP end in 2008 was therefore well regarded and the idea then that CARP could be prolonged was deemed almost impossible (Lim 2009, 5-6). Furthermore, a concurrent Market-Led Agrarian Reform (MLAR) championed by the World Bank held that land distribution on voluntary terms, rather than by expropriations, was optimal. But MLAR, as Borras $(2009,14)$ points out, achieved extremely limited distribution at a cost approximately six times higher than even the state-mediated model, it was not a fit solution to any protiller movement. Herein lies a significant point of bifurcation among local civil society organizations engaged in agrarian reform, and which is focal for the analysis in this paper. Contextually, Herring $(1999,2)$ points out a paradox in 
the politics and philosophy of agrarian reform: where the political change needed for real reform must be made to work through the existing political process itself, little or nothing can be expected to happen. Only under revolutionary or interventionist conditions, as in China, Taiwan, South Korea and Japan in the mid-20 ${ }^{\text {th }}$ Century, might general effective change happen (Putzel 1992, 116). Along this line of reasoning, perhaps ironically, the far left national democratic platform in the Philippines mirrored that of the conservative right in seeking an end to CARP, yet for entirely different reasons. For the ND, CARP maintains the status quo and prevents real change; for the landowners, CARP and the Constitutional arrangements governing it prevents them from making windfall profits from land conversions or sales.

The insistence of the ND had consistently been for a Genuine Agrarian Reform Program (GARP) that eliminated loopholes and pointedly ignored elite special pleading and the right of landowners to market-based compensation (Riedinger 1995, 149-151). As in the decision of the Communist Party of the Philippines (CPP) to boycott the elections of 1986 that ultimately collapsed the Marcos regime and which split the party, (see Riedinger 1995, 127), the decision to reject the continuation of CARP poses acute questions for the ND bloc and those it represents: is it sequestered from power and influence or does it create arguments that the state must eventually answer?

The coalition of civil society organizations called "Reform CARP Movement" (RCM) supporting the CARPER was constituted by center-left reformist groups that might be loosely termed "Social Democratic" (SD), pro-poor branches of the Catholic Church, and associated peasant groups, particularly the Bukidnon peasant farmers of Sumilao (Lim 2009, 52). At stake was a platform of issues overshadowing the specific intentions of the Bukidnon farmers. These included the future of the DAR; prospects for Constitutional Change, as had been long argued for by negotiators on behalf of foreign investment interests, prohibited since 1987 from open or full ownership of Philippine land holdings; peasant resistance of all affiliations to elite ownership; media and academic interests; aid donors; and state budget comptrollers. The RCM proclaimed success on August 7, 2009 with the signing into law of Republic Act No. 9700 (CARPER), which extended CARP implementation until 2014. The following sections looks further into three positions occupied by civil 
society organizations involved in the campaign for and against the enactment of CARPER in 2009.

\section{Civil Society Involvement in the CARPER Campaign}

For this paper, interviews were conducted with leaders of three civil society organizations composed of or representing farmer and peasant organizations directly and centrally involved in the 2009 CARPER campaign. These organizations were Pakisama-National Confederation of Small Farmers' and Fishers' Organizations (Pakisama), Centro Saka Inc. (CSI), and AMIHANNational Federation of Peasant Women (Amihan), all of which were purposively selected to represent three positions occupied by civil society groups throughout the CARPER campaign-namely, grassroots supporter/organizer and NGO supporter from the SD alliance, and grassroots opposition/organizer from the ND bloc. Three face-to-face interviews were conducted at the offices of the respective organizations in the first week of December, 2011, while follow-up sessions were done via telephone and e-mail. The interviewees were Socrates Banzuela, National Coordinator of Pakisama; Romeo Royandoyan, Executive Director of CSI; and Estrelita Mariano, Deputy Secretary-General of Amihan. All interviewees were asked the same platform of questions, from which they were given relative freedom to elaborate.

A brief background about each organization is provided below, followed by an analysis of their commonalities and schisms and the implications of these on civil society participation in agrarian reform in the Philippines. While the three organizations ably represent three distinct perspectives on the CARPER campaign, other perspectives, such as those from the Catholic Church, the state Department of Agrarian Reform (DAR), and landlords or landed legislators, could not be included due to the limited timeframe available for the research. Some representatives did not reply to invitations. Nevertheless, the information offered by the three interviewees sufficed for the purpose of meeting this paper's specific objectives to describe the nature and extent of civil society participation and fragmentation in the 2009 CARPER campaign from a Gramscian perspective. 
(1) Pakisama and the Pro-CARPER Coalition

A principal actor in the pro-CARPER campaign was the Pakisama National Confederation of Small Farmers' and Fishers' Organizations (Pakisama), which consists of 49 federations in 42 provinces of the Philippines and has been active since 1986. They were a member of the Congress for a People's Agrarian Reform (CPAR) until it disbanded in 1993. Riedinger (1995, 141) described CPAR as "a unique alliance of ideologically diverse peasant, fisherfolk and non-governmental organizations." Until now, Pakisama represents the interests, petitions, and grievances of agrarian communities and works in multilateral ways to draw attention to farmers' needs and effect action on their behalf. These efforts include marketing, liaisons, making public statements; calling on support groups, encouraging student activism, building advertising campaigns, lecturing, and conducting workshops, as well as teaching requisite entrepreneurial skills. They have made coalitions with alternative law groups, the influential Catholic Bishops Conference of the Philippines (CBCP), arranged funding, held press conferences, and dealt directly with state actors by petitioning the DAR and lobbying Congress. In addition to their support for the Sumilao farmer's march to Manila in both 1997 and 2007, Pakisama has supported efforts to retrieve the Coconut Levy Fund that was established under the Marcos regime and is understood as having been plundered at will by Marcos's cronies at the expense of the coconut farmers it was nominally intended to serve (Royandoyan 2007); it also supported an organization of small farmers of Antipolo that for 18 years has been seeking title to 1,507 hectares of land owned by Manila Water. Ongoing work includes campaigns in Angaras, Quezon Province, where a free port construction project covering 13,000 hectares has displaced 3,000 Indigenous Persons and farmers (Banzuela 2011).

(2) Amihan and the GARP-Focused ND Bloc

The AMIHAN-National Confederation of Peasant Women (Amihan) has been active since 1988. They organize, educate, and mobilize women, and "bolster the dignity of farmers." They also publish information and education 
materials and conduct education workshops toward building unity among and capacity for peasant women and families. They likewise provide support services and succor to peasant women raped in the course of the struggle, and to those in bereavement as a result of assassination or untimely death. Also, they have been in consistent opposition to CARP, and in subsequent opposition to CARPER. As an affiliated member of the Kilusang Magbubukid ng Pilipinas (KMP) or Peasant Movement of the Philippines, part of the ND bloc, Amihan's position vis-à-vis CARP and CARPER is fundamental and unyielding: both programs are anti-peasant; pro-landlord; and cannot address the real needs of the farmers of the Philippines under the current political framework that implicitly and explicitly favors wealthy, landed families.

Also, as part of a KMP, Amihan is calling for the existing agrarian reform structures to be repealed and replaced with a Genuine Agrarian Reform Program (GARP). This latter program would reconfigure priorities to ensure support and services to reform beneficiaries, and compensation only to landlords whose holdings are proven to have been legally acquired without bloodshed or force. Their actions have involved rallies, lobbying, protests, petitions, sit-ins, so-called "die-ins", in which the plight of farmers is signified by representations of death through starvation and violence. Their engagements that garnered massive media and public attention include the Hacienda Luisita campaign in central Luzon and the Looc estate campaign in Southern Tagalog. The Looc estate covers land that should have gone to peasant beneficiaries but has allegedly been seconded to landed elites represented by the Ayala Corporation and tycoon Lucio Tan for conversion to resort and residential construction. Also, they have been active in Mindanao in efforts to reverse the awarding of land under CARP to Central Mindanao University which had previously been occupied and worked by the native Lumad people. They support land occupations in Negros Occidental, and lobby the legislature on GARP motions. Other members of the alliance include the farmer's group represented in Philippine Congress by the Anakpawis Party-list and other regional and provincial fisherfolk and peasant groups organized under the National Democrat banner. The alliance is wholly in agreement on the antiCARPER project. Their work in Mindanao is wholly separate from that of the groups like Pakisama that allied with the Sumilao farmer marchers from Bukidnon to Manila (Mariano 2011). 
(3) Centro Saka Inc. as the "Third Way"

The third organization, Centro Saka Incorporated (CSI), is a coalition of NGOs that claims to have 500 member farmer organizations across the Philippines. CSI has been active since September 2005 working in "policy research, policy advocacy, networking, capability building and economic linkaging work on agrarian reform and rural development issues, in partnership with people's organizations" (Centro Saka 2011). It uses media and its own publications to target policy makers and make liaisons for promoting development and agrarian reform. According to Romeo Royandoyan (2011), a campaigner for over 30 years on peasant farmers' issues and Executive Director of CSI, the CARPER campaign is a good example of the strong pressure that can be exerted by civil society on the state to achieve policy action and change that benefits ordinary rural Filipinos.

(4) CARPER and the Rural Poor: Convergence and Disagreement

There are four main areas related to CARPER and agrarian reform in general, in which all parties' interests converge: the significant role of the church in rural issues; the impact of the Hacienda Luisita decision; the factor of violence and state coercion; and the question of state commitment to rural development and farmers' welfare.

In general, Pakisama is allied to the Catholic Church and sees advantage in gaining the CBCP's support and leverage, and Centro Saka sees the utility in this liaison. Amihan, on the other hand, is averse to certain positions taken by the church (for most issues, this is mutual). For example, whereas the church sees GARB as unrealistic and communistic partly because of the National Democratic insistence on free land distribution, Amihan's response is that the church ignores the existing fact of the unpaid labor of women and children, as empirically tested by Flores-Obanil $(2008,20)$. By implication, the Church is aligned too closely with landlord interests and against those of the laborers to be a reliable partner.

On the specific question of CARPER, Centro Saka and Pakisama are agreed that it is necessary, just and appropriate as a tool for implementing the 
redistribution of the outstanding 1.2-1.3 million hectares of privately held lands. Amihan disagrees: although they concur that the outstanding private lands must be redistributed, they feel that loopholes introduced by Congressman Pablo Garcia, a representative from Cebu, to ensure that landlords could nominate beneficiaries, and that an attestation oath be taken before a court official, rather than under DAR auspices, prove the disutility of the law and that its service is not to the people it is meant to benefit but to the landowners. Also, provisions to the effect that farmers must prove their productive use of the land and that they must pay back a market-based rate of compensation while under subsistence economy terms are designed to let the land return in due course to the landlord. More even than this, existing beneficiaries have had their land titles (Certificates of Land Transfer, for example) revoked since the advent of CARPER. Taken together, they argue, these conditions make CARPER worse than CARP. As corroborating data, Mariano (2011) cites the fact that not more than 60,000 hectares per year have been redistributed thus far, leaving CARPER seemingly incapable of completing its mandate before closure of the program in 2014.

In assessing CARPER, Royandoyan (2011) and Banzuela (2011) agree that despite its huge 150 billion pesos (roughly, US\$ 3.5 billion) budget, it will likely be slow in implementation; both also recognize that the attestation clause is egregious. Nevertheless, both see CARPER as having been instrumental in the Supreme Court's decision to return Hacienda Luisita to the farmers who have worked it for generations. Banzuela (2011) argues that the Hacienda Luisita judgement shows the value of participatory action as powerfully as that of the Sumilao March, even though it was done without the intervention of the Church. Royandoyan (2011) notes that the Supreme Court cited CARPER in its final decision regarding the redistribution of Hacienda Luisita, which thus serves as a good locus for the shared interests of all opposition groups. Amihan (2011), conversely, argue that the Hacienda Luisita decision was independent of CARPER and, instead, an inevitable result of years of unrelenting pressure on the state to carry out the articles of the law, and the hacienda's own charter from well before the implementation of CARP. All three groups see Hacienda Luisita as a test case and that it will prove to be the precedent towards quicker resolution of other sticky or controversial cases. ${ }^{4}$ 
All groups are fundamentally opposed to the use of force by the state, and deplore the loss of capacity and social capital through assassinations. Royandoyan (2011) notes that the number of assassinations increases with the DAR's effectiveness in redistributing private land. All groups have experienced state pressure during protests or demonstrations; examples include detention and water cannon assault. All three groups believe that the state is not effective or committed to farmers' welfare. This is seen in the failure to ensure support of services in the form of seeds, crop insurance against natural disaster; marketing; road maintenance, and chemical inputs. Royandoyan (2011) furthermore notes that the budget of four billion pesos for essential support services for the DA was cut under the current Benigno Aquino administration; Mariano (2011) states that the reduction in state funding began during the Arroyo administration.

Overall, all groups, regardless of their respective position, outlook and strategies, hold that the state is not adequately motivated to support Philippine agriculture or improve the peasants' welfare. Banzuela (2011), not pessimistically, sees the ongoing need for dialogue, contact, rapport and enthusiasm for the potential of the state to act effectively. Royandoyan (2011) agrees that CARPER cannot carry out its mandate on time, but from a different approach he specifies the problem of the ND bloc not joining the CARPER campaign and notes that this paradoxically aligned the landlords and the far left, although for entirely different ends, as mentioned earlier (Mariano (2011) considers this assertion to be part of a ploy to delegitimize the far left bloc). Royandoyan (2011) notes firstly that the GARB is good in principle but that it cannot work under the existing political set up: it requires a total state commitment that includes free or uncompensated redistribution of lands, which is unlikely to obtain in the foreseeable future. The alternative is to act with what options are available and to insist on the law's implementation as it stands.

\section{ANALYSIS: CIVIL SOCIETY FRAGMANTATION AND THE CARPER CAMPAIGN}

Sen's ideas on substantive and instrumental freedoms were introduced in the framework in order to demonstrate that they fit aptly within the neoliberal paradigm by sidelining a historical reckoning of prevailing conditions and 
structures. Also, by invoking a regime of cooperation between public and private suppliers of healthcare and education, for example, Sen's ideas endorse the market on its own terms and legitimize the practices and policies of the state while coaxing both to do better in securing adequate solutions for such human development indices as the MDGs.

On the other hand, a Gramscian analysis of hegemonic processes arguably is better able to explain certain flaws in Sen's approach. First, voiding the concern with historical processes leaves particular types of contest or impasse at the civil society level difficult or impossible to understand. Second, Sen's approach defers an understanding of how the state and the market not only constitute an existing ruling force hegemony in countries like the Philippines but are also bloc forces vying for hegemonic space with respect to each other. This has important consequences for civil society as organizations must make accommodations with or resist each bloc, respectively, with a view to their own survival and capacity to gain attention and resources for their work. Third, Sen's point of practical departure, human development projects, assumes certain prior conditions such as the ability of farmers to feed themselves and their families. In the Philippines, as Banzuela (2011) describes, such assumptions cannot be taken as given. In other words, arguments for structural change require debate and understanding. Dismissing or eliminating the voices of those who call for such change is contrary to both Sen's substantive freedoms and anything to do with human development. It is thus a Gramscian approach following Roseberry's (1994) elaboration that is used here to deliver analysis of the interviews. First, the primary actor-groups involved in the 2009 CARPER campaign, along with the discourses each group deployed throughout the campaign are analysed.

The principle actors were either pro- or anti-CARPER. The pro-CARPER bloc included left-of-center CSOs in a provisional alliance with elements of the Catholic Church and SD political figures, as well as bureaucrats and, ultimately, executive decision-makers of the state. They organized under the banner of the Reform CARP Movement (RCM). The anti-CARPER positions were occupied by two groups acting in mutual exclusivity: the ND bloc and landed legislators. The justifications given or discourses used for these respective positions included: 1) pro-CARPER: the need for a renewed law to continue implementing an incomplete CARP, particularly since large tracts of 
privately held lands remained undistributed despite the specific provisions of the 1986 Constitution to award land to impoverished farmers. Also, an alternative proposal, the ND's GARP-redistribution along Brazil's MST lines-was deemed unconstitutional by center-left organizations and unacceptable to the Catholic Church; 2) anti-CARPER: according to the ND bloc, CARP failed because of the loopholes built into it to favour landlords; any extension of CARP without complete elimination of such loopholes would create an expensive failed program, producing ample opportunities for corruption without addressing either landlessness or rural poverty. Only a GARP would be acceptable; 3) anti-CARPER: from the perspective of the landed legislators, CARP failed because of insufficient protection for the landlords and insufficient incentives and support for land beneficiary farmers to productively farm and own the land $\left(14^{\text {th }}\right.$ Congress $\left.2009 \mathrm{a} ; 2009 \mathrm{~b}\right)$. This resulted in abandonment, indebtedness or, ironically, return of the land to the former landlord-owner. What all groups do agree on is that small scale rural farmers remain poor because they do not own their lands and lack support from the state to keep lands productive.

In Gramscian terms, the configuration of dominant and subaltern powers in the CARPER debate can be described in the following way: the ruling forces comprise the central state under former President Arroyo's administration and landed legislators, particularly those from Luzon and Visayas where the population of indigent farmers is relatively high. The subaltern groups comprise rural small scale farmers and landless peasants represented by the ND bloc of organizations and a left-of-center alliance of SD organizations organized under the RCM banner. These representative groups concur, for example on the principle of redistributing Hacienda Luisita but differ on how the objective is achieved and what it means. The SD alliance is composed of "People Power" participants from the 1980s; rejectionist former ND activists from the 1990s; anti-Arroyo and anti-Benigno Aquino campaigners from the 2000s onwards; as well as independent campaigners specifically interested in the CARPER issue. The ND bloc, by contrast, involves ideological "People Power" participants; reaffirmist activists from the 1990s; Marxist-LeninistMaoist grounded radicals; anti-Arroyo and anti-Aquino campaigners. These groups share no alliance with the anti-CARPER landlord legislators.

What, given this representation, are the success or failure implications of 
CARPER for Philippine agrarian reform, especially when compared with the relative successes in Brazil by the MST (see Wolford 2003; 2010)? First, certain areas of convergence among the disparate interests obtain: all sectors agree that poverty incidence among small scale farmers and landless peasants is very high because they are not given and cannot afford the necessary resources, tools, infrastructure, marketing and legal/social support to successsfully own land, productively use land, and contribute to agricultural development. The primary question is how to address this problem. For the SDaligned groups, the terms of the Constitution must be worked within, under which CARPER is the best available option because it includes the state, does not alienate the market or the Church and promotes incremental progress that can be measured. In other words, on this issue, the RCM provide consent to the state and other dominant stakeholders. Effectively, they constitute an instrument or appendage of the state that affirms its legitimacy. They act as a filter or buffer between the farmers in need and the need for a properly responsive state to its citizens, consistent with Sen's (2000) conceptions of what constitutes 'civil society'; and, from a Gramscian perspective, they moderate but do not change the prevailing state-society relations. However, this can be seen as a set of relations viz the state and the farmers of a particular intensity and reliability. It is mutable, since the organizations have their own survival to consider with respect to the change of administration from Arroyo to Aquino, the regional and global economic conditions, and the leverage possibilities of accepting in good faith the state as a provisional partner.

The ND position is that the fundamental problem lies within the 1987 Constitution that marginalizes the general subaltern population and promotes the interests of the ruling forces. The boundaries of the Constitution must necessarily be challenged and the best option for agrarian reform is not CARPER but GARP. This position is orthodox, consistent, and inflexible. In other words, opportunities for convergence with other CSOs in the agrarian reform arena are not obvious and are unlikely to obtain unless and until, for example, a sudden systemic shock occurs. Waiting for such conditions to occur is of no use to landless or indigent peasant farmers or to agricultural development. While the Catholic Church remains dominant in the Philippines and while the cult of personality among the dynastic regional and national 
political class continues to be uninterruptable and unchallenged, including under the current administration's agglomeration of Senate leaders (known as "Team P-Noy") in the 2013 elections, change to the existing conditions is unlikely.

From a Gramsican standpoint, the campaigning and alliance-making over CARPER offers evidence of convergences and divergences of differential intensity in a time-dependent manner, as Moyo and Yeros (2005) emphasized to be true across the developing world. First, given that the ND bloc is a fundamentally organized group, their structures are clear and their message is unequivocal. By contrast, the loose grouping of SD has core alliances that form and reform depending on the prominence of an issue, the momentum, the risks and rewards from exposure, the timing, and general political climate. This apparent independence of the SD group is also a contributing factor in their overall weaknesses, and arguably one reason why the state can afford to engage or defer their petitions at will. Here, the Catholic Church plays the effective and strong counterpart or alternative to any possible unification of campaigns with the ND bloc. The underlying problem, however, is that if Royandoyan (2011) is correct in anticipating a food crisis, both the National Democrats and Social Democrats will be able to make use of the conditions that obtain to further their own arguments without any necessary rapprochement among them or, possibly, the necessary capacity to force the hand of the state beyond the point of retraction or ability to renege on its promises. For the foreseeable future, continued fragmentation and divergence and awkward terms of convergence, such as between the ND bloc and conservative landowners, looks likely to continue. What potentials for convergence as might exist do not offer the idea of a seamless fabric covering all subaltern forces or their occasional alliances with dominant powers. Instead, the overall appearance is more of a jealously guarded patchwork of efforts or 'turfing' toward no unified end. There is less convergence discernible than continued, relatively stable fragmentation.

\section{CONCLUSION}

This paper presents a case study of state-civil society relations in respect 
of agrarian reform, a key tenet of the post-Marcos democratic Constitution of the Philippines. The issue in question was the campaign to extend and reform the CARP in a bill signed into law in 2009 known as CARPER. The campaign was supported primarily by an alliance of left-of-center civil society organizations, the Church and certain state bureaucrats. The campaign was opposed by the leftist National Democrats and conservative landlords and landlord legislators. The differential or anomalous positions taken by these forces from a Gramscian perspective is highly revealing of state-society conditions in the Philippines in the late neoliberal era regarding opportunities for policy and program convergence or causes for divergence.

For the ND bloc, free distribution of "solid lands" (i.e., acquired illegally) to the dispossessed is fundamental. This compares to a qualified extent with the interests of the MST in Brazil to create land distribution for the landless within the terms of the constitution but despite the parameters of the law regarding private property. Yet the terms of equity this idea is founded on differs for other actors in the Philippine debate. Church principles of natural law, property rights, and the market economy have generally allied with those of landlords and the idea of equitable transfer of land to their descendents. Any opposition movement's acceptance of free market principles has had to accommodate itself within the neoliberal framework pushed strongly under Gloria Arroyo, and which has continued under the Aquino administration (Borras 2008). This has included the promotion and practice of MLAR which, as Borras (2009) tabulates it, is the least effective and most expensive. In this sense, both the disappointment of civil society leaders like Banzuela (2011) and Royandoyan (2011) with the Aquino administration and Mariano's (2011) lack of surprise are highly relevant. Indubitably the two groups are still separated by what each anticipate and expect of the current political process, based on the ideals they and their organizations represent. In this setup, there appears to be a potential for civil society convergence but without any clear sense of what the tipping point to terms of unity might be. What is clear is that concrete counter hegemonic resistance, peasant participation and agrarian reform languish while such issues are unresolved.

All groups that campaigned for or against CARPER agree that the state is negligent in respect of the agriculture sector. The costs of such failings, if 
production shocks ensue, will fall disproportionally on those who can least fend for themselves, and whose voices are consistently ignored or kept in abeyance. This is a recurrent pattern from at least as early as the Marcos-era land reform. Consequently, development prospects for peasants are injured not only through deficits in participation at the decision-making and planning levels but also due to the inability of participating civil society groups to influence policy decisively. In a Gramscian sense, there is no concerted war for position while CSOs work to ensure their own survival under a formidable neoliberal paradigm that rewards civil society with flows of funds for compliance with the prevailing political and market orthodoxy but that ignores or stifles critics.

\section{REFERENCES}

$14^{\text {th }}$ Congress of the Republic of the Philippines. 2009a. Congressional Record 5(81). Monday, June 1, 2009.

$14^{\text {th }}$ Congress of the Republic of the Philippines. 2009b. Congressional Record 5(82a). Monday, June 3, 2009.

Abinales, Patricio N. and Donna J. Amoroso. 2005. State and Society in the Philippines Manila: Anvil.

Aguilar, Filomeno V. 2005. Rural Land Struggles in Asia: Overview of Selected Contexts. In, Reclaiming the Land: The Resurgence of Rural Movements in Africa, Asia and Latin America, eds. Sam Moyo and Paris Yeros. London: Zed Books.

Akram-Lodhi, Haroon. 2007. Land, Markets and Neoliberal Enclosure: An Agrarian Political Economy Perspective. Third World Quarterly 28(8): 1437-1456.

Banzuela, Socrates. 2011. Interview at Pakisama office, Quezon City on 1 December 2011.

Bebbington, Anthony and Graham Thiele. 1993. Non-Governmental Organisations and the State in Latin America: Rethinking Roles in Sustainable Agricultural Development. London: Routledge.

Bello, Walden. 2009. The Anti-Development State: the political economy of permanent crisis in the Philippines. Manila: Anvil. 
Borras, Saturnino M. 2001. State-Society Relations in Land Reform Implementation in the Philippines. Development and Change 32(2001): 545575.

Borras, Saturnino M. 2003. Questioning Market-Led Agrarian Reform: Experiences from Brazil, Columbia and South Africa. Journal of Agrarian Change 3(3): 367-394.

Borras, Saturnino M. 2008. Competing Views and Strategies on Agrarian Reform Vol. II: Philippine Perspectives. Quezon: Ateneo de Manila University Press.

Borras, Saturnino M., Danilo Carranza and Jennifer Franco. 2007. Anti Poverty or anti poor? The World Bank market led agrarian reform experiment in the Philippines. Third World Quarterly 28(8): 1557-1576.

Borras, Saturnino. M., Cristobal Kay and Haroon Akram-Lodhi. 2007. Agrarian Reform and Rural Development: Historical Overview and Current Issues. Land, Poverty and Public Action Policy Paper No. 1. The Hague and New York: Institute of Social Studies and UNDP.

Borras, Saturnino M., Danilo Carranza, Jennifer Franco and Mary Ann Manahan. 2009. Anti-Land Reform Land Policy? The World Bank's Development Assistance to Agrarian Reform in the Philippines September, 2009. Focus on the Global South, Overseas Aid and Agrarian Reform. Retrieved December 10, 2011 from http:/www.landaction.org/ $\mathrm{IMG} / \mathrm{pdf} / \mathrm{wb}$-final.pdf.

Boudreau, Vincent. 2001. Grass Roots and Cadre in the Protest Movement. Quezon City: Ateneo de Manila University Press.

Business World. 2011. November 24. Farmers preparing to own lands in Cojuangco sugar estate. Business World. Retrieved from http://www.bw orldonline.com/content.php?section $=$ Nation\&title $=$ Far mers-preparingto-own-lands-in-Cojuangco-sugar-estate $\&$ id $=42237$.

Calderon, Jose F. 1978. Rice Production and Land Reform. Manila: Cen-tro Escolar University R\&D Center.

De Jesus, Edilberto C. 1982. 'Conclusion: An Agenda for Philippine Stu-dies' In Philippine Social History: Global trade and local transformations, eds. Alfred W. McCoy and Edilberto C. de Jesus. Quezon City: Ateneo de Manila University Press. 
Fernandes, Bernardo M. 1999. MST, Movimento dos Trabalhadores Ru-rais

Sem-Terra: Formação e Territorialização. São Paulo: Editora Hucitec.

Flores-Obanil, Carmina B. 2008. Rural Development Review 2008: Validation

Survey Results: private agricultural land distribution under CARP. Quezon City: Centro Saka.

Flores-Obanil, Carmina B. 2010. Bringing Filipino agrarian reform back to life? Notes on the passage of the CARPER law. Land Struggles: LRAN Briefing Paper Series (July 2010).

Fox, Jonathan. 1990. Editor's Introduction. In The Challenge of Rural Democratization: Perspectives from Latin America and the Philippines, ed. Jonathan Fox. London: Frank Cass and Co, Ltd.

Franco, Jennifer. 2000. Campaigning for democracy: grassroots citizen-ship movements, less-than-democratic elections, and regime transition in the Philippines. Quezon City: Institute for Popular Democracy.

Franco, Jennifer and Saturnino Borras. 2005. On Just Grounds: Struggling for agrarian justice and citizenship rights in the rural Philippines. Quezon City: Institute for Popular Democracy.

Harvey, Neil. 1998. The Chiapas Rebellion: The Struggle for Land and Democracy Durnham: Duke University Press.

Hedman, Eva.-Lotta E. 2006. In the name of civil society: From free election movements to people power in the Philippines. Quezon City: Ateneo de Manila University Press.

Heredia, Beatrix, Leonilde Medeiros, Moacir Palmeira, Rosangela Cintrao, and Sergio Pereira Leite. 2006. Regional Impacts of Land Reform in Brazil. In Promised Land: Competing Visions of Agrarian Reform, eds. Peter Rosset, Raj Patel and Michael Courville. Canada: Institute for Food and Development Policy.

Herring, Ronald J. 1999. Political Conditions for Agrarian Reform and Poverty Alleviation, 2001 World Development Report on Poverty. DFID Conference Proceedings, Birmingham, England, August 16-17, 1999. Retrieved from http://siteresources.worldbank.org/INT POVERTY/Resources/ WDR/DfiD-Project-Papers/herring.pdf

Hickey, Samuel and Giles Mohan. 2004. Participation: from tyranny to transformation? Exploring new approaches to participation in development. 
New York and London: Zed Books.

Hobsbawm, Eric. 1974. Peasant Land Occupations: Past and Present. Oxford Journals 62(1): 120-152.

Ileto, Reynaldo C. 1979. Pasyon and Revolution: Popular movements in the Philippines, 1840-1910. Quezon City: Ateneo de Manila University Press.

Keane, Kathryn. 2012. Conceptualizing Civil Society: The New Left's Reorganization of Civil Society in Latin America. Undergraduate Journal of Global Citizenship 1(2): 1-40.

Kerkvliet, Benedict T. J. 1979. The Huk Rebellion: A study of peasant revolt in the Philippines. Quezon City: New Day.

Kerkvliet, Benedict T. J. 1991. Everyday Politics in the Philippines: Class and Status Relations in a Central Luzon Village. Quezon City: New Day Press. Lahiff, Edward. 2007. 'Willing Buyer, Willing Seller': South Africa's Failed Experiment in Market-Led Agrarian Reform. Third World Quarterly 28(8): 1577-1597.

Lim, Ernesto. 2009. Carper: The triumph of the Filipino Peasantry. Quezon City: AR Now!.

Mariano, Lita. 2011. Interview at Amihan Peasant Women's Organization office, Quezon City on 1 December 2011.

McAndrew, John P. 1994. Urban Usurpation: From Friar Estates to Industrial Estates in a Philippine Hinterland. Quezon City: Ateneo de Manila University Press.

Moore, Barrington. 1967. Social Origins of Dictatorship and Democracy: Lord and Peasant in the Making of the Modern World. Boston: Beacon Press.

Moyo, Sam and Paris Yeros. 2005. Introduction. In Reclaiming the Land: The Resurgence of Rural Movements in Africa, Asia and Latin America, eds. Sam Moyo and Paris Yeros. London: Zed Books.

Navarro, Zander. 2000. Breaking New Ground: Brazil's MST. NACLA Report on the Americas 33(5): 36-39.

Ncube, Cornelias. 2010. Contesting Hegemony: Civil Society and the Struggle for Social Change in Zimbabwe, 2000-2008. Doctoral dissertation thesis submitted to the University of Birmingham, U. K., September 2010.

Ofreneo, Rene E. and Melissa R. Serrano. 1991. Problems and prospects of AR implementation at the village level in the Philippines. Quezon City: UP 
School of Labor and Industrial Relations/Fri-edrich-Ebert Stiftung.

Olea, Ronalyn V. 2009. Why CARPER is worse than CARP. Bulatlat. Retrieved from http://bulatlat.com/main/2009/06/14/why-carper-is-worsethan-carp/.

Petras, James. 1997. Latin America: The Resurgence of the Left. New Left Review 223: 17-47.

Pratt, Nicola. 2004. Bringing Politics Back In: Examining the Link between Globalization and Democratization. Review of International Political Economy 11(2): 1-26.

Putzel, James. 1992. A Captive Land: The politics of agrarian reform in the Philippines. Ateneo de Manila University Press: Manila.

Reid, Ben. 2000. Philippine Left: Political Crisis and Social Change. Manila and Sydney: Journal of Contemporary Asia Publishers.

Reid, Ben. 2008. Development NGOs, Semiclientelism, and the State in the Philippines: From "Crossover" to Double-crossed. Kasarinlan: Philippine Journal of Third World Studies 23(1): 4-42.

Reyes, Celia M. 2002. Impact of Agrarian Reform on Poverty. Philip-pine Institute of Development Studies Discussion Paper Series No. 2002-02. Retrieved from http://www3.pids.gov.ph/ris/pdf/pidsdps 0202.PDF.

Roseberry, William. 1994. Hegemony and the Language of Contention. In Everyday Forms of State Formation: Revolution and the Negotiation of Rule in Modern Mexico, eds. Gilbert M. Joseph and Daniel Nugent. Durham: Duke University Press.

Riedinger, Jeffrey M. 1995. Agrarian reform in the Philippines: demo-cratic transitions and redistributive reforms. Stanford CA: Stanford University Press.

Robles, Wilder. 2001. The Landless Rural Workers Movement MST in Brazil. Journal of Peasant Studies 282: 146-161.

Royandoyan, Romeo C. 2011. Interview at Centro Saka office, Quezon City, 5 December 2011.

Royandoyan, Romeo C. 2007. Long and Tortuous Road to Coconut Levy Recovery. Rural Development Review. Quezon City: Centro Saka.

Sadomba, Wilbert and Kirk Helliker. 2009. Transcending Objectifications and Dualisms: Farm Workers and Civil Society in Contemporary Zimbabwe. 
Journal of Asian and African Studies 45(2): 209-225.

San Juan, Epifanio. 2013. Antonio Gramsci's Theory of the 'NationalPopular' as a Strategy for Socialist Revolution. In Perspectives on Gramsci: Politics, culture and social theory, ed. Joseph Francese. London: Routledge.

Scott, James C. 1985. Weapons of the Weak: Everyday Forms of Pea-sant Resistance. Yale: Yale University Press.

Scott, James C. and Benedict T. Kerkvliet. 1986. Everyday Resistance to Injustice in a Philippine Village. Journal of Peasant Studies 13(2): 107123.

Sen, Amartya. 2000. Development as Freedom. New Delhi: Oxford University Press.

Serote, Ernesto M. 2004. Property, Patrimony and Territory: foundations of Land Use Planning in the Philippines. Quezon City: UP Planning and Development Research Foundation.

Sidel, John, T. 1995. The Philippines: The Languages and Legitimation. In Political Legitimacy in Southeast Asia, ed. Muthian Alagappa. Stanford: Stanford University Press.

Scokpol, Theda. 1979. States and Social Revolutions: A Comparative Analysis of France, Russia, and China. New York and Cambridge: Cambridge University Press.

Suárez, Sofia M. 2013. The Human Rights Framework in Contemporary Agrarian Struggles. The Journal of Peasant Studies 40(1): 239-290.

Tilly, Charles. 1978. From Mobilization to Revolution. Boston: Addi-sonWesley.

Weekley, Kathleen. 2001. The Communist Party of the Philippines. New York: Routledge.

Wolf, Eric R. 1969. Peasant Wars of the Twentieth Century. Oklahoma City: Oklahoma University Press.

Wolford, Wendy. 2003. Families, Fields, and Fighting for Land: The Spatial Dynamics of Contention in Rural Brazil. Mobilization: An International Journal 8(2): 201-215.

Wolford, Wendy. 2005. Agrarian moral economies and neoliberalism in Brazil: competing worldviews and the state in the struggle for land. Environment 
and Planning 37(1): 241-261.

Wolford, Wendy. 2010. Participatory Democracy by Default: land reform, social movements and the state in Brazil. Journal of Peasant Studies 37(1): 91109.

Wurfel, David. 1988. Filipino Politics: development and decay. In G. Kahin (ed.), Politics and International Relations in Southeast Asia. Ithaca: Cornell University Press.

Yamsuan, Cathy C. 2012, May 23. High drama highlights Corona's day in court. Philippine Daily Inquirer. Retrieved from http://newsinfo. Inquirer.net/198537/high-drama-highlights-corona\%E2\%80\%99s-day-in-court. 


\section{ENDNOTES}

1 The coalition was called the "Reform CARP Movement" (RCM).

2 Representatives from Bayan Muna (People First) Party, Gabriela Women's Party, Anakpawis Party, and Kabataan (Youth) Party.

3 Among several other organizations approached to participate in the study only these three responded within the research period.

4 Notably, the undue pressure put on the judiciary by the present Aquino government has been raised as a factor behind the Hacienda Luisita decision. The Chief Justice, who was appointed by Macapagal-Arroyo under contentious terms and subsequently prosecuted by the Aquinoallied House of Representatives, was a major force behind the decision (Yamsuan, 2012, May 23). This highlights the highly political nature of the estate's distribution, even outside civil society's direct participation. 